\title{
THE EFFECT OF BODY SHAMING ON INSTAGRAM ON STUDENT'S CONFIDENCE
}

\author{
Harisa Ninda Siti Ramadhany \\ Universitas Negeri Jakarta, HarisaNindaSitiRamadhany_1410619043@mb.unj.ac.id
}

\author{
K. Y.S. Putri \\ Universitas NegeriJakarta, kinkinsubarsa@unj.ac.id
}

\section{(a) (1) ()}

(C)2020 by the authors. Submitted for possible open access publication under the terms and conditions of the Creative Commons Attribution-ShareAlike 4.0 International License (CC-BY-SA) license (https://creativecommons.org/licenses/by-sa/4.0/)

15) DOI : bttp:// dx.doi.org/10.30983/ humanisme.v5i2

\begin{tabular}{l|l|l} 
Submission : June 14, 2021 & Revised : December 12, 2021 & Published : December 31, 2021
\end{tabular}

\begin{abstract}
Social media is used to express someone's personal image and connect with anyone. Not only that, many people play social media to display their advantages. So it is undeniable that everyone can compare each other like physical insults or body shaming like social media. This study aimed to determine whether there is an effect of body shaming on Instagram on the trust of female students in the Communication Studies program, State University of Jakarta. The method used in this study is a quantitative method with an explanatory format. The researcher collected data using a questionnaire distributed through a link to 37 respondents, and the sampling technique used was a simple random sampling technique. The results of this study indicate an effect of body shaming on Instagram on female students' self-confidence. The regression coefficient value obtained in this study is $Y=22.788+0.285 X$ with a significance level of 0.000 less than 0.05 , so it can be concluded that the $X$ variable affects the $Y$ variable. Body shaming on Instagram on female students' self-confidence by $6.9 \%$ with a shallow category and the rest is influenced by other things outside of this study, such as the psychological component.
\end{abstract}

Keywords : Body Shaming, Self Confidence, New Media

\begin{abstract}
Abstrak
Media sosial digunakan sebagai wadah untuk mengekspresikan diri dan berhubungan dengan siapapun itu. Tak hanya itu, banyak orang yang memainkan media sosial hanya untuk memajang kelebihannya. Sehingga tak bisa dipungkiri, layaknya media sosial, setiap orang pasti bisa membandingkan satu sama lain seperti penghinaan fisik atau body shaming. Tujuan dari penelitian ini adalah untuk mengetahui apakah ada pengaruh body shamming di Instagram terhadap kepercayaan mahasiswi di program studi Ilmu Komunikasi Universitas Negeri Jakarta. Metode yang idigunakan dalam penelitian ini adalah metode kuantitatif dengan format explanatory. Peneliti mengumpulkan data menggunakan kuesioner yang disebarkan melalui link kepada 37 responden dan Teknik penentuan sampel menggunakan Teknik simple random sampling. Hasil penelitian ini menunjukkan bahwa terdapat pengaruh body shaming di Instagram terhadap kepercayaan diri mahasiswi, nilai koefisien regresi yang diperoleh dalam penelitian ini adalah $\mathrm{Y}=22,788+0,285 \mathrm{X}$ dengan tingkat signifikans 0,000 lebih kecil dari 0,05 , sehingga dapat disimpulkan bahwa variabel $\mathrm{X}$ berpengaruh terhadap variabel $\mathrm{Y}$. Angka tersebut menunjukkan bahwa pengaruh body shaming di Instagram terhadap kepercayaan diri mahasiswi sebesar 6,9\% dengan kategori sangat rendah dan selebihnya dipengaruhi oleh hal-hal lain di luar dari penelitian ini, seperti komponen psikologi
\end{abstract}

Kata Kunci : Body Shaming, Kepercayaan Diri, New Media 


\section{Introduction}

Social media was born because of the encouragement of various application features present on the existence of the internet. According to McQuail, social media can be explained as media in the form of communication tools and social activities in the form of contributing to external audiences. ${ }^{1}$

Indeed, the use of social media has a significant influence on our lives today. Social media such as Instagram, Twitter, and Facebook are used to publish icons such as material for activities or various opinions of users, as media that provide a space for communication and interaction in social networks in the world. ${ }^{2}$

Social media is used as a place to express yourself and connect with anyone. Not only that, many people play social media just to display their advantages. So, it is undeniable, like social media, everyone can definitely compare each other like physical people or body shaming.

Artists and the children of Indonesian artists experience physical situations or body shaming. They received unpleasant comments from the public on social media, such as the case of Tasya Kamila, Eva Celia and Raisa, and they died because their bodies were too fat or too skinny. ${ }^{3}$

In a 2016 "Body Peace Resolution" survey conducted by Yahoo! Health showed that women receive more physical insults than men. A survey of 2,000 people aged 16-64 found that women experienced body

${ }^{1}$ Mulawarman \& Nurtifi, Perilaku Pengguna Media Sosial beserta Implikasinya Ditinjan dari Perspektif Psikologi Sosial Terapan, Buletin Psikologi, Vol. 25, Issue 1, 2017, h. 36-44.

${ }^{2}$ R. Nasrulloh, (2016), Teoridan Riset Media Siber (Cybermedia), Jakarta: Kencana.

${ }^{3}$ N. A. Masithoh, Body Shame pada Mahasiswa Generasi Milenial di Universitas Negeri Semarang, Semarang : UNNES. shaming, while only $64 \%$ of men experienced body shaming. ${ }^{4}$

Physical insults in cyberspace usually occur on social media, especially Instagram. Based on data on complaints of physical harassment cases, Indonesia handled a total of 966 cases of physical harassment throughout $2018 .^{5}$

Women are more likely to become victims of body shaming because the culture of society's development always requires women to have their beauty standards. For example, it is said that if one have a slim body, then a slim body is gorgeous.

Previous research has done much research on body shaming. Research conducted by Rita Nasrul and Rinaldi in 2020 with the title "Relationship with BodyShaming and Self-confidence in SMAN 5 Pariaman students" to find out the correlation between body shaming and self-confidence over the age at SMAN 5 Pariaman. This study uses quantitative methods with criteria for adolescents with less than ideal bodies and acne-prone faces.

Data collection using a confidence scale. The data is processed using the product-moment correlation technique and this study proves that there is a minisignificant correlation of body shame with self-confidence at SMAN 5 Pariaman. ${ }^{6}$

Furthermore, a study entitled "The Effect of Body Shaming on Self-Esteem of Junior High School Students" was researched by Nani Barorahi Nasution and Ernita Simanjuntak in 2020. This study used a quantitative method using a survey conducted on 242 students of SMPN 2 Datuk Lima

4 K. Miller, "The Shocking Results", www.yahoo.com/lifestyle. Diakses tanggal 10 April 2021.

${ }^{5}$ Gani\& Jalal, Persepsi Remaja Tentang Body Shaming, Jurnal IKRA-ITH Humaniora, Vol. 5, Issue 2, 2020, h. 156.

${ }^{6}$ Nasrul \& Rinaldi, Hubungan Body Shame dengan Kepercayaan Diri Pada Siswa SMAN 5 Pariaman. Jurnal Riset Psikologi, Vol.20, Issue 2, 2020, h.1-14. 
Puluh with a sample of 60 students. The results of data analysis using simple linear regression show that a reduction will follow each addition of one unit of the bodyshaming score in the score of the self-esteem level. $^{7}$

Then there is a study entitled "BodyShaming Through Social Media as a Digital Crime In The Era of Disruption" conducted by Mohamad Rusdiyanto U. Puluhulawa and Riski Husain in 2021. The problem raised in this study is what legal factors influence the prevalence of body shaming as a digital crime in the era of disruption. The approach method used is conceptual. In conclusion, the legal substance and legal culture are the legal factors that influence the prevalence of body shaming. It is recommended to improve regulations and the role of the press and the public to change their perspective on body shaming behavior. ${ }^{8}$

Then the study entitled "The Effect of Cyberbullying Body-Shaming on Instagram Social Media on the Confidence of Career Women in Pekanbaru" by Dela Geofani in 2019. The purpose of this study was to determine whether there is an effect of cyber bullying body shaming on Instagram social media on the confidence of career women in Pekanbaru. The method used in this research is a quantitative method with an explanatory format. Researchers collected 100 data which were filled out using a questionnaire distributed via a link, and the technique for determining the sample was random sampling. The results of this study indicate that cyber bullying has an effect on body shaming on social media, especially

7 Nasution \& Simanjuntak, Pengarub Body Shaming Terhadap Self-Esteem Siswa SMP. Jurnal Pendidikan :Teori, Penelitian \& Pengembangan, 2020, h. 1-15.

${ }^{8}$ Puluhulawa \& Husain, Body Shaming Through Social Media as a Digital Crime In The Era of Distruption. Jalrev :Jambura Law Review, 2021.
Instagram, on the self-confidence of career women in Pekanbaru.

Based on this background, the researchers tried to enrich the findings about Body-Shaming by looking at the description of body shaming in women, predominantly female students. Researchers want to see how much influence body-shaming has on students in their late teens. So the purpose of this study is to determine whether bodyshaming affects self-confidence in women, especially female students in the Communication Studies program, State University of Jakarta, Class of 2019.

\section{Conceptual Overview}

\section{a. Body Shaming}

Body shame is a very strong form of shame. The body is a part of ourselves that is directly observable to others, but it is also a personal seat that allows a meaningful experience of the subject.

Body shame can be understood as a body-centered feeling in which the subject believes that this body is undesirable or unattractive, far from socially acceptable images of the ideal or body. ${ }^{10}$

Body shaming or commenting on someone's physique can be classified as verbal or verbal bullying. In short, physical humiliation can be interpreted as a negative attitude or behavior towards a person's weight, body size, and appearance. ${ }^{11}$

Body shaming can cause psychological problems for patients because this action includes acts of violence. Body-shaming we

${ }^{9}$ Geofani, Pengaruh Cyber bullying Body Shaming Pada Media Sosial Instagram Terhadap Kepercayaan Diri Wanita Karir di Pekanbaru, JOM FISIP, Vol. 6, Issues 2, 2019, h. 1-15.

${ }^{10}$ Dolezal, "The Body and Shame: Phenomenolgy, Feminism, and the Socially Shaped Body",http://centreformedicalhumanities.org. Diakses tanggal 11 April 2021.

${ }^{11}$ Tri Fajariani Fauzia \& Lintang Ratri Rahmiaji, Memahami Pengalaman Body Shaming Pada Remaja Perempuan, Interaksi Online, Vol. 7, Issue 3, 2019, h. 238-248. 
often encounter accidentally around us, even on purpose.

Body shaming also has characteristics such as criticizing one's own appearance through a comparison with others, criticizing other people's appearance in front of that person, and criticizing other people's appearance without their knowledge. ${ }^{12}$

Body shaming is usually associated with women who have less than ideal bodies. Because this woman is not ideal so her appearance is not very attractive. The impact of globalization has touched all aspects of their lives, including having a good body or appearance. ${ }^{13}$

Aspects of body shaming based on Gilbert \& Miles are:

a. Social or external cognitive component

This condition is the thought of an individual who judges another individual as a person who is not good or low.

b. Emotional component

Emotions or feelings that usually occur are feelings of shame such as anger and anxiety about oneself. This can happen because of a negative view of oneself.

c. Behaviour component

When there are feelings or emotions such as shame, they tend to avoid the surrounding environment. It will be feel uncomfortable because there are unfavorable views from other people so that they feel ostracized. ${ }^{14}$

\section{b. Self-confidence}

Self-confidence is a person's belief and behavior in their own abilities when they accept what is positive and negative, what is formed and learned through the learning

${ }^{12}$ C. Lisya, Body Shame dan Gangguan Makan Kajian Meta-Analisis. BuletinPsikologi, Vol. 26, Issue 1, 2018, h. 12-27.

${ }^{13}$ Surya Ananda Fitriana, Dampak Body Shaming Sebagai Bentuk. Kekerasan Perempuan, 2019, Jakarta : UIN Syarif Hidayatullah Jakarta.

${ }^{14}$ Chairani,L.Body Shame dan Gangguan Makan Kajian Meta-Analisis, Buletin Psikologi,Vol 26, Issue 1,2018, h. 12-27 process for the ultimate goal of making themselves happy. ${ }^{15}$

Self-confidence is one of the basic requirements for us to carry out activities and creativity to achieve a goal. However, selfconfidence will not increase by itself. Trust begins with a healthy interaction process in a person's social environment and continues continuously. Believe in yourself because there is a certain process within us to build self-confidence. ${ }^{16}$

There are several aspects of selfconfidence as expressed by Lauster (2002) are:

a. Confidence in one's abilities

Self-confidence can be interpreted as an individual's belief to be able to behave in accordance with what is expected and desired.

b. Optimism

Optimism is a positive attitude possessed by individuals who always try to have a good view in everything.

c. Objective

People who view a problem according to the truth, not according to themselves or others.

d. Responsible

The individual's willingness to bear everything that has become the consequence.

e. Rational and realistic.

How does an individual analyze a problem or a thing by using an acceptable mind following reality. ${ }^{17}$

15 Tika Nurul Ramdhani \& Flora Grace Putrianti, Hubungan Antara Kepercayaan Diri Dengan Citra Diri Pada Remaja Akbir, Jurnal UST Jogja : SPIRITS, Vol. 4 , Issue 2, 2019, h. 22-32.

${ }^{16}$ Asrullah Syam \& Amri, Pengaruh Kepercayaan Diri (Self Confidence) Berbasis Kaderisasi IMM Terhadap Prestasi Belajar Mahasiswa (Studi Kasus di Program Studi Pendidikan Biologi Fakultas Keguruan dan Ilmu Pendidikan Universitas Muhammadiyah Pare Pare), Jurnal Biotek, Vol. 5 , Issue 1, 2017, h. 87-102

17 Ghufron, M.Nurdan Risnawita S, Rini. (2010). Teori-Teori Psikologi. Yogyakarta. Ar-Ruzz Media. 


\section{c. Instagram}

Instagram is a photo - sharing application that allows users to take photos, apply digital filters, and share them on various social networking services such as Instagram itself. $^{18}$

One of the main goals of Instagram itself is to become a favorite tool for every individual who wants to post events, products, locations, or himself either in the form of photos or videos. ${ }^{19}$.

\section{Research Model}

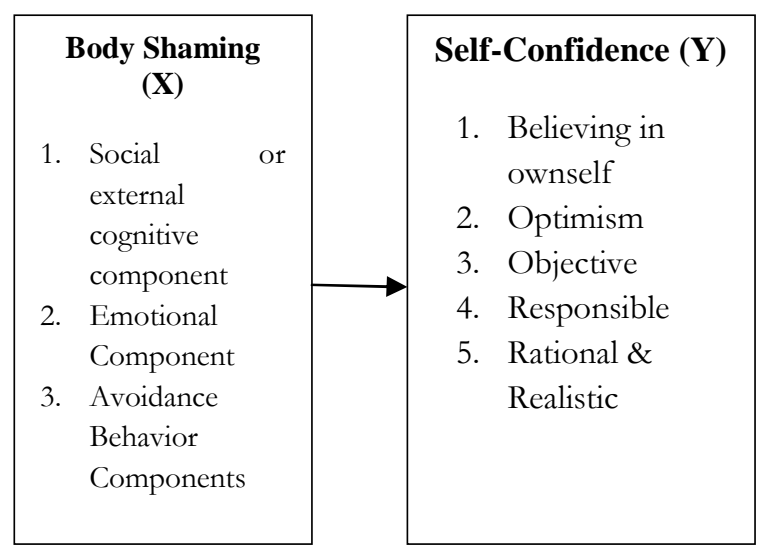

Source: Reseacher's data,2021

\section{Hypothesis}

Based on the conceptual review and research model above, the following hypotheses are:

$\mathrm{H}_{\mathrm{a}}$ : There is an influence between body shaming on Instagram and self-confidence in female students at the Communication Studies Program, State University of Jakarta.

$\mathrm{H}_{\mathrm{o}}$ :There is no effect between body shaming on Instagram and self-confidence in female students at the Communication Studies Program, State University of Jakarta.

${ }^{18}$ Damas Rambatian Rakanda, Penggunaan Media Sosial Instagram Dalam Pembentukan Identitas Diri Generasi $Z$ atau I generataion di Desa Cawas, 2020, Fakultas Ilmu Sosial dan Ilmu Politik, Yogyakarta :Universitas Pembangunan Nasional "Veteran".

${ }^{19}$ Mahendra, B. Eksistensi Sosial Remaja Dalam Instagram. Jurnal Visi Komunikasi, Vol 16,Issue 1, 2017, h. 151-160.

\section{Method}

\section{a. Types of research}

This study uses quantitative research methods with an explanatory format. Quantitative research with an explanatory format aims to explain the relationship between two or more symptoms or variables $^{20}$.

In this study two variables are connected. The causal relationship is a causal relationship between the independent variable (X), namely body shaming and the dependent variable $(\mathrm{Y})$ namely self-confidence.

\section{b. Place and time of research}

This research was conducted through Google Form. Researchers chose Google Form as a means to facilitate research due to the Covid-19 pandemic.

The time spent by researchers for this research starts from April 2021 until it ends in July 2021. The time of this research starts from pre-study with the completion of the research report.

\section{c. Population and Sample}

Population is a group of individuals, events or interesting things that researchers want to investigate to make a conclusion based on sample statistics. ${ }^{21}$ The population in this study were all female students in the Communication Studies Program, State University of Jakarta, Class of 2019, which amounted to 57 people.

The sampling technique in this research is purposive sampling. Purposive sampling is a sampling technique with certain considerations. ${ }^{22}$ The sample of this study was a student of the 2019 Jakarta State University Communication Studies Program, aged 19-21 years. The number of samples taken as many

${ }^{20}$ Silalahi, U. (2015). Metode Penelitian Kuantitatif, Kualitatif dan R \& D. Bandung: Alfabeta.

${ }^{21}$ Sekaran,Uma. (2016). Research Methods for Business $\left(7^{\text {th }} \mathrm{ed}\right)$. West Sussex: Wiley.

${ }^{22}$ Ghozali, I. (2016). Desain Penelitian Kuantitatif dan Kualitatif. Yoga Pratama. 
as 37 respondents determined by using the Slovin formula.

\section{d. Data Collection Technique}

The data collection technique used in this study was a questionnaire. The researcher used data collected in a questionnaire to obtain significant data in the research design. Questionnaires were given by researchers that already contained statements related to body shaming on Instagram and student selfconfidence. Later the researchers will distribute the questionnaires made via google forms and distribute them via the link.

\section{Discussion and Analysis}

This chapter is a presentation of research results with the data analysis process.

\section{a. Validity test}

Validity is the level of certainty between the data seen from the research object and the strength of the results, it can be concluded that the data being tested is valid data. ${ }^{23}$

An indicator is said to be valid if the indicator statement is able to reveal something that is measured by the indicator. In essence, it can be said to be valid, meaning that the instrument can be used to measure what it is supposed to measure. ${ }^{24}$

To test the validity, the Kaiser MeyerOlkin (KMO) Measure of Sampling Adequacy was used, an index used to test the suitability of the analytical model. The validity test using $\mathrm{KMO}$ can be valid if it meets the requirements, namely the KMO value 0.5 and the Significant value (Sig.) < 0.5 , which means it is adequate. The data is not valid if the KMO value shows $<0.5 \mathrm{i}$, which means that the factor analysis is not adequate.

\footnotetext{
${ }^{23}$ Sugiyono, (2015) ,Metode Penelitian Kuantitatif, Kualitatif, dan $\mathrm{R} \& \mathrm{D}$, Bandung: Alfabeta.

${ }^{24}$ Malhotra,N.K. (2010). Marketing Research : An Applied Orientation ( $\sigma^{\text {th }}$ ed). Pearson Education.
}

Table 1. Validity Test on X Variable KMO and Bartlett's Test

\begin{tabular}{ccc}
\hline $\begin{array}{c}\text { Kaiser- Meyer- Olkin Measure of } \\
\text { Sampling }\end{array}$ & Adequacy. \\
\hline $\begin{array}{c}\text { Bartlett's Test of } \\
\text { Sphericity }\end{array}$ & $\begin{array}{c}\text { Approx.Chi- } \\
\text { Square }\end{array}$ & 75,280 \\
\cline { 2 - 3 } & df & 21 \\
\cline { 2 - 3 } & Sig. &, 000
\end{tabular}

Source :Reseacher's data,2021

The study's validity test of the BodyShaming variable $(\mathrm{x})$ showed that the KMO value was 0.812 . It means that this variable $\mathrm{x}$ data is valid because it fulfills the signal, namely the KMO value i0.5 and the Significant (Sig.) $<0.5$.

Table 2. Validity Test on Y Variable KMO and Bartlett's Test

\begin{tabular}{lcc}
\hline \multirow{2}{*}{$\begin{array}{c}\text { Kaiser- Meyer- Olkin Measure of } \\
\text { Sampling }\end{array}$} & Adequacy. \\
\hline $\begin{array}{c}\text { Bartlett's Test of } \\
\text { Sphericity }\end{array}$ & $\begin{array}{c}\text { Approx.Chi- } \\
\text { Square }\end{array}$ & 106,892 \\
\cline { 2 - 3 } & df & 36 \\
\cline { 2 - 3 } & Sig. &, 000 \\
\hline
\end{tabular}

Source : Reseacher's data,2021

The test of the validity of the variable (y) Confidence in the study showed that the $\mathrm{KMO}$ value was 0.676 . It means that this data variable $y$ is valid because it fulfills the signal, namely the value of iKMO i0.5 and the value of significant (Sig.) $<0.5$.

\section{b. Reliability Test}

Reliability is a quality measurement method that shows that the same data have been collected in repeated observations of the same phenomenon. This reliability is closely related to the accuracy and precision of measurement. ${ }^{25}$

Reliability testing is done by analyzing the value of Cronbach alpha in statistical data. The research instrument can be said to be reliable with the condition that the Croncbach alpha value $\geq 0.6$.

\footnotetext{
${ }^{25}$ Babbie, E. (2016). The Practice of Social Research $\left(14^{\text {th }} \mathrm{ed}\right)$. Cengage Learning.
} 
Table 3.Reliability Test on (X) Variable Reliability Statistics

\begin{tabular}{lrr}
\hline Cronbach'sAlpha & N of Items \\
\hline &, 815 & \\
\hline
\end{tabular}

Source :Reseacher's data,2021

The reliability test of the Body Shaming variable $(\mathrm{x})$ in this study showed the Cronbach alpha coefficient value of 0.815 . It means that the data variable $(\mathrm{x})$ is reliable. This data meets the requirements of reliability which is said to be reliable if the value of Croncbach alpha $\geq 0.6$.

Table4. Reliability Test on (Y) Variable Reliability Statistics

\begin{tabular}{llll} 
Cronbach'sAlpha & N ofItems & \\
\hline &, 804 & 9
\end{tabular}

Source :Reseacher's data, 2021

The reliability test of the selfconfidence variable (y) in this study showed the Cronbach Alpha coefficient of 0.804. It means that the data variable $(y)$ is reliable. This data meets the requirements of reliability which is said to be reliable if the Croncbach alpha value is $\geq 0.6$.

\section{c. Simple Linear Regression Analysis}

This hypothesis test is processed by comparing the $\mathrm{T}_{\text {count }}$ value with the $\mathrm{T}_{\text {table }}$ value. This test is also often referred to as the $\mathrm{T}$ test. Researchers used SPSS 25 in this study. In this test whether the two variables have an effect, namely between body shaming on female students' self-confidence.

Table 5. Statistic Measurement

\begin{tabular}{|c|c|c|c|c|c|}
\hline $\begin{array}{l}\mathrm{N} \\
\mathrm{o} .\end{array}$ & Variable & $\begin{array}{c}\text { Variable } \\
\text { Coeffici } \\
\text { ent }\end{array}$ & $\begin{array}{l}\text { Tarithme } \\
\text { tic }\end{array}$ & T Table & $\begin{array}{l}\text { Significat } \\
\text { ion }\end{array}$ \\
\hline 1. & Constant & 22,788 & 5,613 & 2,030 & 0.000 \\
\hline 2. & $\begin{array}{c}\text { Body } \\
\text { Shaming }\end{array}$ & 0,285 & & & \\
\hline
\end{tabular}

Based on Table 5 which is the output of SPSS 25, it can be seen that the results of a simple linear regression obtained the coefficient value in this research regression is $\mathrm{Y}=22.788+0.285 \mathrm{X}$. The constant value of
22.728 means that if the body shaming is zero, the self-confidence value is 22.728 units. The regression coefficient for the body shaming variable is 0.285 , meaning that each increase in the body shaming value by one unit will increase self-confidence by 0.285 units. In this study, it was obtained that $\mathrm{T}_{\text {count }}$ was 5.613 which was greater than $T_{\text {table, }}$ which was 1.984 , with a significance level of 0.000 less than he $=0.05$, so it can be concluded that the $\mathrm{X}$ variable affects the $\mathrm{Y}$ variable, it can be concluded that there is an effect of body shaming on Instagram on the selfconfidence of students in the Communication Science study program, State University of Jakarta, it means that $\mathrm{Ha}$ is accepted, Ho is rejected.

\section{d. Coefficient of Determination Test}

The coefficient of determination basically measures how far the model's ability to explain the variation of the independent variable is. The value of the coefficient of determination is between zero and one. ${ }^{26}$

The value of the coefficient of determination can be seen below:

\begin{tabular}{|c|c|c|c|c|}
\hline \multicolumn{5}{|c|}{ Table 6. Coefficient of Determination } \\
\hline & & & Adjusted R & Std.Erroroft \\
\hline Model & $\mathrm{R}$ & $\overline{\text { R Square }}$ & Square & heEstimate \\
\hline 1 & $262^{a}$ & ,069 & ,042 & 3,362 \\
\hline
\end{tabular}

Source :Reseacher's data, 2021

Based on Table 6 , the coefficient of determination shows that the coefficient of determination obtained is 0.2622 and the coefficient of determination (iRsquare) is i.i.i. This figure shows that the effect of body shaming on Instagram on female students' self-confidence is $6.9 \%$ with a very low category and the rest is influenced by other things outside of this study. This means that the effect of body shaming on Instagram on female students' self-confidence based on the

\footnotetext{
${ }^{26}$ Gozali, Nanang \& Nasehudin, (2015) ,Metode Penelitian Kuantitatif. Bandung :Pusaka Setia.
} 
coefficient of determination table is categorized as having a very low influence.

So based on the results of the research conducted, the researcher will discuss the study's results entitled "The Effect of BodyShaming on Instagram on Students' SelfConfidence," where the researcher initially made a questionnaire which was the primary data source in this study. The questionnaire made was then distributed to the respondents who in this case, were students of the Communication Studies program at the State University of Jakata who had experienced body shaming on Instagram. The questionnaire was distributed via a link, then it can be accessed via Google Drive so that respondents can fill out the questionnaire online.

Based on Table 1, the results of the test of the validity of the variable $\mathrm{x}$ and Table 2 , the results of the test of the validity of the variable $y$, it can be seen that the two variables were declared valid because they met the requirements, namely the KMO value $\mathrm{u} 0.5$ and the Significant value (Sig.) $<u 0.5$. Based on Table 3 , the results of the reliability test for the variable $\mathrm{x}$ and Table 4 , the results of the reliability test for the variable $y$, it can be seen that the two variables are declared reliable where the value of Cronbach's alpha is greater than 0.6.

After the questionnaire was declared valid and reliable, the next researcher distributed questionnaires to 37 respondents determined based on the slovin formula. Researchers also distributed the questionnaire through a link sent via private chat, which would later be connected to Google Drive. The data obtained is then processed by Microsoft Excel and SPSS 25 to be used for the linear regression test process and also the determination test.

Based on Table 5 which is the output of SPSS 25, it can be seen that the results of simple linear regression obtained the regression coefficient value in this study is $\mathrm{Y}$ $=22.788+\mathrm{i} 0.285 \mathrm{X}$.

Meanwhile, based on Table 6, the coefficient of determination shows that the coefficient of determination obtained is 0.2622 and the coefficient of determination $\left(\mathrm{R}_{\text {square }}\right)$ is 0.2622 due to squaring the correlation coefficient $0.262 \times 0.262$. This figure shows that the effect of body shaming on Instagram on female students' selfconfidence is $6.9 \%$, with a very low category. While the remaining $93.1 \%$ was influenced by several other factors not included in this study, such as the psychological component.

\section{Conclusion}

Based on the results obtained by the researcher, that body shaming on Instagram affects student self-confidence. It can be seen from the results of simple regression analysis that $\mathrm{T}_{\text {count }}$ is 5.613 which is greater than $\mathrm{T}_{\text {table }}$, which is 2.030 with a significance level of 0.000 less than $\mathrm{a}=0.05$, so it can be concluded that variable $\mathrm{X}$ has an effect on variable Y. Meanwhile the coefficient of determination ( $\mathrm{r} 2$ ) obtained is 0.2622 and the coefficient of determination $\left(\mathrm{R}_{\text {square }}\right)$ is $0.262 \mathrm{x}$ 0.262. This figure shows that the effect of body shaming on Instagram on female students' self-confidence is $6.9 \%$ with a very low category and the rest is influenced by other things outside of this study, such as the psychological component.

\section{Solution}

No one should judge or feel ashamed of their appearance. We only have one body and we must be able to accept and love ourselves. Other people will always have something to say and we definitely cannot please everyone.

So the solution to the body-shaming problem in this study is that we cannot live with what other people expect of us, so live in our own way and learn to accept and love 
ourselves. We have to learn how to feel good about ourselves because we deserve it.

\section{Bibliography}

\section{Journal :}

Fauzia, T. F., \& Rahmiaji, L. R. (2019). Memahami Pengalaman Body Shaming Pada Remaja Perempuan. Interaksi Online, 7(3), 238-248.

Gani, \& Jalal. (2020). Persepsi Remaja Tentang Body Shaming. Jurnal IKRA-ITH Humaniora, 5(2), 156.

Geofani. (2019). Pengaruh Cyberbullying Body Shaming Pada Media Sosial Instagram Terhadap Kepercayaan Diri Wanita Karir di Pekanbaru. JOM FISIP, 6(2), 1-15.

Lisya, C. (2018). Body Shame dan Gangguan Makan Kajian Meta-Analisis. Buletin Psikologi, 26(1), 12-27.

Mahendra, B. (2017). Eksistensi Sosial Remaja Dalam Instagram. Jurnal Visi Komunikasi, 16(1), 151-160.

Mulawarman, \& Nurtifi. (2017). Perilaku Pengguna Media Sosial beserta Implikasinya Ditinjau dari Perspektif Psikologi Sosial Terapan. Buletin Psikologi, 25(1), 36-44.

Nasution, \& Simanjuntak. (2020). Pengaruh Body Shaming Terhadap SelfEsteem Siswa SMP. Jurnal Pendidikan: Teori, Penelitian \& Pengembangan, 1-15.

Ramdhani, T. N., \& Putrianti, F. G. (2019). Hubungan Antara Kepercayaan Diri Dengan Citra Diri Pada Remaja Akhir. Jurnal UST Jogja: SPIRITS, 4(2), 22-32.

Syam, A., \& Amri. (2017). Pengaruh Kepercayaan Diri (Self Confidence) Berbasis Kaderisasi IMM Terhadap Prestasi Belajar Mahasiswa (Studi Kasus di Program Studi Pendidikan Biologi Fakultas Keguruan dan Ilmu Pendidikan Universitas Muhammadiyah Pare-Pare). Jurnal Biotek, 5 (1), 87-102.

Books :

Babbie, E. (2016). The Practice of Social Research (4th ed.). Cengage Learning.

Dolezal. (2021). "The Body and Shame:
Phenomenolgy, Feminism, and the Socially Shaped Body." http:/ / centreformedicalhumanities. org.

Ghozali, I. (2016). Ghozali, I. (2016). Desain Penelitian Kuantitatif dan Kualitatif. Yoga Pratama.

Ghufron, M.Nur. (2010). Teori-Teori Psikologi. Yogyakarta. Ar-Ruzz Media.

Gozali, Nanang, \& Nasehudin. (2015). Metode Penelitian Kuantitatif. Pusaka Setia.

Malhotra, N. K. (2010). Marketing Research: An Applied Orientation (6th ed.). Pearson Education.

Masithoh, N. A. (2020). Body Shame pada Mahasiswa Generasi Milenial di Universitas Negeri Semarang. UNNES.

Miller, K. (2021). "The Shocking Results",. www.yahoo.com/lifestyle

Nasrulloh, R. (2016). Teori dan Riset Media Siber (Cybermedia). Kencana.

Puluhulawa, \& Husain. (2021). Body Shaming Through Social Media as a Digital Crime In The Era of Distruption. Jalrev: Jambura Law Review.

Rakanda, D. R. (2020). Penggunaan Media Sosial Instagram Dalam Pembentukan Identitas Diri Generasi $Z$ atau Igenerataion di Desa Cawas. In Fakultas Ilmu Sosial dan Imu Politik.

Saidah, N. (2015). Hubungan Antara Kepercayaan Diri Dengan Kemandirian Belajar Siswa Akselerasi MAN 1 Model Bojonegoro. In Fakultas Psikologi.

Sekaran,Uma. (2016). Research Methods for Business ( $7^{\text {th }}$ ed). West Sussex : Wiley.

Silalahi, U. (2015). Metode Penelitian Kuantitatif, Kualitatif dan $\mathrm{R} \& \mathrm{D}$. Alfabeta.

Sugiyono. (2015). Metode Penelitian Kuantitatif, Kualitatif, dan R \& D. Alfabeta.

Surya Ananda Fitriana. (2019). Dampak Body Shaming Sebagai Bentuk Kekerasan Perempuan. UIN Syarif Hidayatullah Jakarta. 